\title{
Institutions and European trade: merchants guilds, $1000-1800$
}

\section{Oscar Gelderblom}

To cite this article: Oscar Gelderblom (2014) Institutions and European trade: merchants guilds, 1000-1800, Business History, 56:6, 1026-1028, DOI: 10.1080/00076791.2013.828425

To link to this article: https://doi.org/10.1080/00076791.2013.828425

\section{曲 Published online: 25 Sep 2013.}

Submit your article to this journal 4

Џlll Article views: 204

Q View related articles ¿

View Crossmark data ¿ 
overloaded discourse. By focusing on what he calls the ecosystem of the City, Sunderland makes the finances of the Raj more transparent, and sheds new light on the economics of the British Empire in India.

Tirthankar Roy

London School of Economics and Political Science t.roy@lse.ac.uk

(C) 2013, Tirthankar Roy

http://dx.doi.org/10.1080/00076791.2013.828424

Institutions and European trade: merchants guilds, 1000-1800, by Sheilagh Ogilvie, Cambridge, Cambridge University Press, 2011, vi + 493 pp., £22.99 (paperback), ISBN 978-0-521-74792-9

Medieval and early modern merchant guilds appeal to the imagination of many modern economists who consider them prime examples of institutions for collective action that foster economic development in the absence of strong states. It is certainly an attractive image: informally organised associations of merchants travelling around Europe, using their social capital to enforce contracts and to keep predatory rulers at bay. But this is not what happened, says Sheilagh Ogilvie in her new book Institutions and European Trade. Merchants Guilds, 1000-1800. The vast majority of known merchant guilds were local organisations endowed with more or less extensive privileges from their home government. Likewise, the most famous of the guilds of foreign traders, the German Hanse, was a formal collaboration between town magistrates and merchants for the coordination of protection and contract enforcement abroad. Ogilvie further argues that the merchants who belonged to these guilds often abused their privileged position to pursue private benefits at the cost of society at large.

To substantiate her reinterpretation of the role of merchant guilds in pre-modern economies, Sheilagh Ogilvie has collected an impressive body of evidence on associations of local and long-distance traders throughout Europe, reaching back as far as the tenth century and running all the way through the eighteenth century. This comprehensive historical account is an achievement in its own right but it serves an even more substantial, theoretical purpose. Already in her Tawney Lecture in 2006 Ogilvie pointed out that institutions are too often considered in isolation, as arrangements with a single purpose whose efficiency is measured by their fulfilment of one particular function. In reality, however, institutions often serve multiple purposes while their efficiency typically hinges on economic actors using them in combination with other institutions. To this insight, which goes back to the writings of Frederic Lane on the economic organisation of medieval Venice, Ogilvie adds a further observation, namely that institutions, even the ones that are intended to enhance economic efficiency may seriously harm the economy. This is indeed the key message of the present book: most merchant guilds in pre-modern Europe were rent-seeking organisations which used their economic and extra-economic powers to exclude others from their business and maximise their members' gains.

Ogilvie begins her historical analysis with an overview of the various kinds of mercantile associations that existed throughout Europe until 1500. In the sixteenth century these guilds started to decline, first in the Low Countries and England, and later also in 
other parts of Europe. Institutional economists have linked this decline to the formation of stronger states in this period, but Ogilvie rightly points out that in many places merchant guilds continued to thrive alongside more powerful local or central governments. This coexistence shows that the availability of alternative solutions for protection and contract enforcement did not automatically lead to the decline of guilds. Quite the contrary, Ogilvie argues, it shows that economic efficiency was never the prime objective of these corporate institutions.

The core of the book consists of eight, densely written chapters in which Ogilvie analyses the various economic functions European merchant guilds may have performed, including conflict resolution, information supply, protection against violent assaults, securing market access, and price control. In each of these chapters Ogilvie documents the potentially efficiency-enhancing traits of local and alien merchant guilds; the alternative private and public solutions to economic problems that were simultaneously available to merchants in many locations; and, last but not least, the detrimental effects powerful guilds had in many locations, protecting only their members, keeping information to themselves, or restricting entry to domestic or foreign markets. The fundamental lesson that Ogilvie draws from this historical analysis is that even merchants guilds providing the widest possible range of services to their members remained exclusive, particularised institutions, as opposed to the generalised, open access institutions that first emerged in countries around the North Sea.

With this distinction between inclusive and exclusive institutions Sheilagh Ogilvie puts the rise, persistence, and decline of merchant guilds in pre-industrial Europe right at the heart of the central debate in New Institutional Economics. She points out that those countries in which merchant guilds were replaced by generalised property rights and contracting institutions early on, i.e. England and the Low Countries, were also the fastest growing economies of pre-modern Europe. Merchant guilds were no longer needed in these countries, Ogilvie argues, because merchants had access to alternative private and public solutions for the problems previously solved by the guilds. However, Ogilvie observes, at least part of these generalised institutions were also available in towns in central, eastern, and southern Europe where merchant guilds persisted until the seventeenth or eighteenth centuries. This then leads her to conclude that guilds did not survive because they were an efficient solution to problems that could not be solved otherwise, but because they offered non-trivial benefits to their members.

Institutions and European Trade is a great achievement for at least two reasons. It provides detailed answers to a broad range of questions regarding the organisation of the early modern European economy and it offers a comprehensive theoretical framework to analyse the impact of institutions on economic performance. Only two questions remain unanswered. On the one hand, Ogilvie does not explain what caused the early decline of merchant guilds in England and the Low Countries. She points to the existence of alternative solutions but we remain in the dark about the emergence of these open access institutions. On the other hand, contrary to its conceptualisation of guilds as multifunctional institutions, the book does not explore the total costs - or benefits! - of the combined functions that individual guilds performed. Ogilvie convincingly shows that any single solution offered for a particular problem may benefit the members of a guild to the detriment of society at large, but if this particular guild performed additional services that did enhance general welfare, these social benefits may simply trump the social costs it generated. As Ogilvie has offered such a comprehensive cost-benefit calculus in earlier work on 
German guilds, one can only hope she will do same in further work on European merchant guilds.

Oscar Gelderblom

Utrecht University

o.gelderblom@uu.nl

(C) 2013, Oscar Gelderblom

http://dx.doi.org/10.1080/00076791.2013.828425

L'entreprise et sa mémoire. Mélanges en l'honneur de Maurice Hamon, edited by Didier Bondue (with Roger Nougaret and Bruno Delmas), Paris, Presses universitaires de Paris-Sorbonne, 404 pp., €24.00 (paperback), ISBN 978-2-84050-878-6

Collective books in honour of an academic grandee can be disappointing because of the fragmentation of the topics. But Maurice Hamon has been the archivist of the SaintGobain group since 1971 - and as such he has been perfectly located at the cross-roads of business history and corporate culture. Under the guidance of a few enlightened managers, who became conscious of the 'revolutions' which their group have had to face (nationalisation, thorough changes of the portfolio of strategic activities, and globalisation), Hamon managed to assert himself as a leverage force between the corporate community and the community of business historians. Hamon even contributed to the organising and financing of the first conference on business history, which took place in Blois, France during the mid-1980s. At this conference, the group built an archives centre, a trend that would be followed by few other firms afterwards. The more Saint-Gobain became internationalised, the more its archives and strategy attracted historians. A kind of 'club' gathered about Saint-Gobain to argue about the fate of French firms with open-minded processes of confronting managers, economists, experts of management schools, and, sometimes, historians. Thus, this book goes far beyond a mere tribute to an emeritus academic.

Despite the awkward structure of the book, we can build up several blocks alongside thematic subjects. A first group of texts is dedicated to archives and their history, at SaintGobain and other firms. Business historians of today are used to getting access to wellorganised archive centres; but several chapters reconstitute the process of setting them up. They also ponder issues of methods, of the arguments among archivists, basic recordkeepers, and lawyers to define the meaning, the contents, and the fresh rules to open the files to historians. We are thus reminded of the evolution of the standards of such codes, but also the training of a new 'type' of archivists, decidedly 'business-minded', that are able to understand the corporate culture, the process of decision, the way of exerting power within their own firm and promoting the interests of their archive centres. Several archivists tell how they were stake-holders in such moves in the 1970s-2000s.

A few chapters relate to the key issue of the 'nature' of history within a firm, of the role of its 'memory': Jean-Pierre Daviet, a business historian, insists on the 'patrimonial' role played by history at Saint-Gobain, whilst Alain Baudant - evolving from a historian to a manager in the group - tackles the issue of history as 'literature' within a group concerned mainly with action and management, whilst Félix Torres, himself one of the rare 'public historians' in France, explains how firms can sometimes welcome history as a lever to a better understanding of their 'memory', and may even use history to broaden their ability 